REFLECTIONS:

NEUROLOGY AND

THE HUMANITIES

Section Editor

Anne W. McCammon,

MD, FAAN

Arayamparambil C.

Anilkumar, MD

Correspondence to

Dr. Anilkumar:

anilpedneuro@gmail.com

\section{The Lurching Man}

The Lurching Man from my childhood came to me.

On this small smart screen covered with glass I saw

The iron eye of the tiger on his scan,

But not those of the Lurching Man from my village memories.

I was too young then...

Like his children, with whom I played

And ran away scared, seeing their Dad.

He calls my mother, "Sister... are you there?"

The voice slowly squeezed out of a spastic throat

A much forced out smile dripped as an afterthought.

My sister and I hid till he was gone

Eating the lunch my mother gave

The only food he had in many days.

I am afraid to ask his children now

What they thought about their father.

Maybe they don't want to remember

The nightmare of their younger days.

The contorted face,

The writhing tongue swimming

In drool.

The Lurching Man...

I wanted to help them explore their genes.

But they don't need any charity

Or dug up memories.

Come back Lurching Man.

Maybe, I can help your children.

I am not scared anymore. 


\section{Neurology}

The Lurching Man

Arayamparambil C. Anilkumar

Neurology 2016;86; 34

DOI 10.1212/WNL.0000000000002311

\section{This information is current as of January 25, 2016}

\section{Updated Information \&} Services

\section{Subspecialty Collections}

Permissions \& Licensing

Reprints including high resolution figures, can be found at: http://n.neurology.org/content/86/4/e34.full

This article, along with others on similar topics, appears in the following collection(s):

\section{All Movement Disorders}

http://n.neurology.org/cgi/collection/all_movement_disorders Dystonia

http://n.neurology.org/cgi/collection/dystonia

\section{MRI}

http://n.neurology.org/cgi/collection/mri

Information about reproducing this article in parts (figures, tables) or in its entirety can be found online at:

http://www.neurology.org/about/about_the_journal\#permissions

Information about ordering reprints can be found online: http://n.neurology.org/subscribers/advertise

Neurology ${ }^{\circledR}$ is the official journal of the American Academy of Neurology. Published continuously since 1951, it is now a weekly with 48 issues per year. Copyright @ 2016 American Academy of Neurology. All rights reserved. Print ISSN: 0028-3878. Online ISSN: 1526-632X.

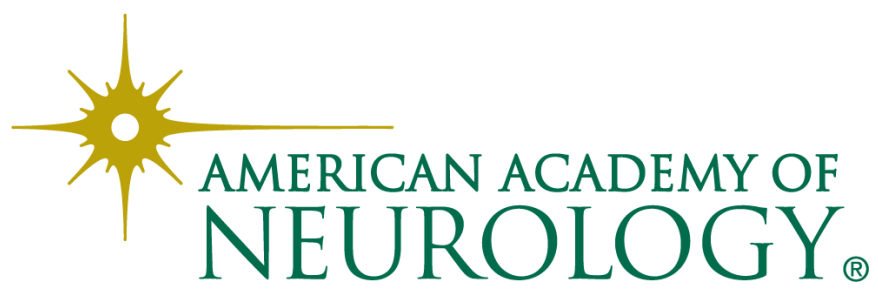

